\title{
A study on the EFL students' speech related anxiety in Taiwan
}

Hsu, Tsu-Chia $\$

Lunghwa University of Science and Technology, Taiwan, ROC (hsuinuk@gmail.com)

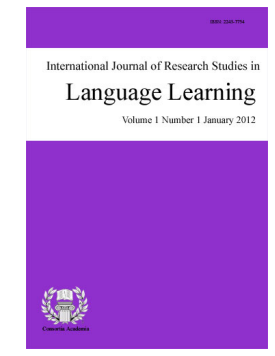

ISSN: 2243-7754 Online ISSN: 2243-7762

OPEN ACCESS

\section{Abstract}

Global challenges in terms of producing more globally competitive graduates have given grounds to the need of students to enhance their English proficiencies. Although most Taiwanese students have studied English starting from their elementary education up to their senior high school years, however, research have shown that there is still a need to improve on the students' English speech proficiency. This presentation details an empirical study which aims to investigate how Public Speaking Anxiety (PSA) affects English as Foreign Language (EFL) students who took a yearlong public speaking course in Taiwan. More specifically, the study seeks to answer these four major concerns: 1.) what are the underlying factors behind the students PSA; 2.) to what extent can gender differences affects PSA and time of preparation for a speech (TPS); 3.) to what extent can gender differences and the different type of audiences affect the reported levels of PSA; and 4.) what are the advantages/disadvantages brought about by the yearlong public speaking course. This case study adopts a mixed-method paradigm, wherein methodology from both quantitative and qualitative is systematically combined. Participants were 82 third-year technical-vocational college students. The Personal Report of Public Speaking Anxiety (PRPSA) quantitative survey was used to determine the level of students' anxiety, while the qualitative focus group interview was accomplished to further understand the effects of PSA and gender differences with respects to TPS and types of audiences. Results show that the yearlong public speaking course had indeed helped diminish some if not all of the students' PSA. Furthermore, relationship between PSA and gender differences of the audience was significant. Lastly, female students have longer TPS and higher reported PSA than male students, however, is caused mainly due to their being grade conscious and fear of performing badly in front of their classmates.

Keywords: public speaking anxiety (PSA); EFL learners; time of preparation for a speech (TPS); gender differences; public speaking skills 


\section{A study on the EFL students' speech related anxiety in Taiwan}

\section{Introduction}

In the past decade, higher education in Taiwan has been changing and growing in an incredible rate. Furthermore, as Taiwan becomes a member of the World Trade Organization in 2002 and together with the signing of the Economic Cooperation Framework Agreement with China last July 2010. Taiwan's higher education institutions are becoming more competitive, while trying to struggle from quantity and quality of education. Within the current paradigm of globalization and internationalization practice, the importance of producing globally competitive graduates has furthered strengthen the need for students to enhanced their English proficiencies.

Although, most Taiwanese students have studied English starting from their elementary education up to their senior high school year, however, there is still a need to improve on the students' English speech proficiency. With this in mind, Taiwan's Ministry of Education (MOE) has encouraged various programs aimed at improving the students' English proficiency. Since, English is highly regarded as the gateway to global marketplace and finding ways to improve not only the students' English proficiency but speaking skills is of the utmost importance (Bassano \& Christison, 1987; Nunan, 2003; Richards \& Renandya, 2002).

In Taiwan, the technological and vocational educational system is already matured and has been quite successful for more than a decade ( $\mathrm{Su}, 2005)$. According to the statistics of the Ministry of Education (MOE) there are a total of ninety-five (95) technical and vocational colleges (Ministry of Education, 2010). Most schools that falls in the category of technological and vocational education have been constantly developing their curriculum to increase their competitiveness. In particular, most of these schools have a Department of Applied Foreign Languages (DAFL) with a main purpose of teaching English for Specific Purposes (ESP) course programs. Within these DAFL, the topic public speaking or oral speaking has already become a required subject.

Upon further analysis, it is found that there are only twelve (12) technical and vocational colleges with applied foreign languages (AFL) department that offers EFL learners English public speaking classes (Ministry of Education, 2010). Having a better English communication skill is useful to most EFL learners, since such skills will be able to help secure better jobs ( $\mathrm{Su}, 2005)$. However, Macintyre and Gardner (1989) mentioned that many students have a negative self-evaluation and expresses fear during foreign language classes, which in turn influenced their public speaking ability. Myers (1999) also mentioned that public speaking can caused anxiety. Yet, in a positive way of thinking when one experienced stress in public speaking, he or she could have a better performance in front of the audiences (Kenneth \& Melvin, 2008).

Therefore, in order to meet the future career demands, most EFL students have pursue not only to upgrade their English capabilities but also to improve on their oral speaking skills, though most students in the process of learning suffers public speaking anxiety. In light of these issues, this paper shall present an empirical study investigating how PSA affects technical-vocational college EFL students who took a yearlong public speaking course in Taiwan.

\section{Literature review}

\subsection{Public Speaking Anxiety}

Spielberger (1983) defined general anxiety as to "the subjective feeling of tension, apprehension, nervousness, and worry associated with an arousal of the autonomic nervous system". Chorpita and Barlow (1998) also mentioned that anxiety is "a state of conceptual or central nervous system characterized by activity 
of the behavioral inhibition system". In fact, everyone has anxiety, especially when the individual is speaking in front of an audience. It is said that public speaking will get even the most prepared person anxious (Paalhar, 2001). Beatty (1988) pointed out that an individual might even suffer from trembling knees, shaking voice, speaking quickly or slowly, or some might even have a flat voice when one's nervous symptom occurs. Furthermore, anxiety can also happen to an individual who has years of public speaking experience. PSA is a very common feeling for most people (Paalhar, 2001).

Many people would feel greater nervousness when they are on the stage and afraid of interacting with the audience. More specifically, when the audience remains in silence, the speakers will get much anxiety, and forget what they want to say (Kenneth \& Melvin, 2008). Within an educational setting, public speaking skills is considered quite important (Bygate, 1987). For EFL learners, the situation regarding speech anxiety might be worsening with the involvement of a foreign language. However, in a study regarding Spanish university students, results show that the student's primary source of anxiety is not speaking in a foreign language, but rather the actual action of speaking in front of the class (Young, 1990). Therefore, knowing how to help EFL students to deal with speech anxiety has long been a major concern of language teachers (Ellis, 1994; Verderber \& Verderber, 2003).

In particular, some students might have negative insight that is caused by the speech evaluation. Horwitz and Young (1991) described that anxiety is an obstacle when we are learning foreign language and trying to speak up. Research have shown that during a foreign language class, when students are speaking in front of their teachers and classmates, that's the moment that they will get the most anxiety (Horwitz \& Young, 1991). In addition, the lack of public speaking experience is also a serious cause of PSA (Verderber \& Verderber, 2003). However, Bygate (1987) mentioned that public speaking can help students in many ways, such as improved retention and enhanced learning motivations. Hence, appropriate public speaking training is said to help improved communication skills and help students succeed academically. After all, public presentations and group discussions are common activities in academic settings (Sun, 2008). However, despite these many advantages that is derived from the development of effective public speaking skills, many students still perceived it as an anxiety provoking classroom activity (Payne \& Carlin, 1994).

With regards to gender difference in public speaking, it is also said that males and females may have different reaction and processing method in handling PSA. In general, the ideology of males often describes as bravery, sense of humor and strong muscles (Haywood \& Mac an Ghaill, 2003), however, females presents physical beauties, and care takers. Campbell and Shaw (1994) revealed a significant interaction between gender and foreign language anxiety. Particularly male students felt more anxious in using a foreign language than female students do. On the contrary, male's anxiety is generated externally, such as: course schedule changing and low English proficiency. In addition, Misra and Mckean (2000) also indicated that there exist a significant gender differences among many measures including academic stress, time management, and anxiety. Hence, if female students have more TPS due to their fear of academic stress and PSA, it follows that male students would exert more TPS in order to diminish their even greater PSA as compared to their female counterparts.

Another significant factor that caused PSA within male and female students in public speaking performance is academic stress. Aida (1994) claimed that Japanese students with previous speech experiences showed a significantly lower level of anxiety than those of novice speakers. In addition, Hsu (2008) also pointed out that male students show more anxious in worrying about their insufficient English ability in class, while female students felt more anxious because of insufficient preparation before speaking in class. It is therefore hypothesized that female's anxiety is generated from within such as: academic stress and fear of inadequate preparation.

In Taiwan, $\mathrm{Wu}$ (2004) mentioned that there exist a positive correlation between a student's language anxiety and English speaking proficiency. Besides having a good atmosphere or a nonthreatening environment to encourage students, a peer supportive atmosphere is said to have successfully reduce students' anxiety levels 
(Chen, 2001; Cheng, Horwitz, \& Schallert, 1999; Chuo, 2005; Wu, 2004) and even increased students' academic achievement (Ghaith, 2002; Slavin, 1980). Some also mentioned that using group work or utilizing a cooperative way of learning is a good way to reduce stage fright (Clément, Dörnyei, \& Noels, 1994). In essence, within cooperative learning situations there is a positive interdependence among students' goal attainments; students perceive that they can reach their learning goals if and only if the other students in the learning group also reach their goals.

In sum, the overall body of speech anxiety research has produced various important findings, such as: PSA is similar to a personality-like trait (McCroskey, Daly, \& Sorensen, 1976), in some people it resembles a temporary state PSA event (Behnke \& Sawyer, 2001), in some ways PSA is associated with various conditions related to the type of audience (Beatty, Behnke, \& McCallum, 1978), it also prompts some speakers to avoid public communication whenever possible (McCroskey, 1984; McCroskey \& Beatty, 1984), it is often associated with physiological symptoms such as sweating, elevated heart rate, and trembling (Clements \& Turpin, 1996), PSA varies across different speech preparation, delivery, and completion (Behnke \& Sawyer, 2001), and many others.

\subsection{The Present Study}

Thus far, most of the previous studies have pointed out the numerous causes of speech anxiety. However, there seem to be a lack in studies regarding possible intervention of PSA. Therefore the current study shall detail an empirical study which aims to investigate how PSA affects technical-vocational college EFL students who took a yearlong public speaking course in Taiwan. This study utilizes a mixed-method research paradigm, wherein the researcher systematically combined or mixed ideas from both quantitative (survey) to understand the underlying factors behind PSA and qualitative (focus group interview) to understand the effect of TPS and various audiences in PSA (Johnson \& Christensen, 2008). More specifically, the study seeks to answer these four major concerns:

1. What are the underlying factors behind the students' PSA?

2. To what extent can gender differences affects PSA and TPS?

3. To what extent can gender differences and the different type of audiences affect the reported levels of PSA?

4. What are the advantages/disadvantages brought about by the yearlong public speaking course?

\section{Methods}

\subsection{Paradigm}

As mentioned before, this study utilizes the mixed-method research paradigm. Mixed method design presents unique opportunities to use multiple sources of information from multiple approaches and gain new insights into the social world (Axinn, Fricke, \& Thornton, 1991). Furthermore, with varying data collection methods, researchers can provide information from one approach that was not identified in an alternative approach, at the same time, reducing non-sampling error by providing redundant information from multiple sources (Axinn \& Pearce, 2006).

This research is also designed as a case study, wherein the primary objective is to investigate a contemporary phenomenon within its real-life context; when the boundaries between phenomenon and context are not clearly evident; and in which multiple sources of evidence are used (Yin, 1984, p. 23). Furthermore, Merriam (1998) views a case as an individual, a program, a class or students, a school, or a community. She fashions the distinctiveness of case studies as particularistic because of the focus on one social unit; descriptive 
because they result in a rich thick portrait; and heuristic because case studies sharpen readers' understanding while leading to a new meanings.

\subsection{Participants}

A total of eighty-two (82) third-year students of a four-year technical-vocational college in Taiwan participated in the study. All of the students were enrolled in a yearlong (two semesters) public speaking course starting from September 2009 to August 2010 school year. Aged between 20 to 25; student participants have garnered an average of 10 years of formal education in learning the English language, prior to their participation in this study. All of the 82 students participated in the quantitative part of the study, which is to fill up the McCroskey (1970) Personal Report of Public Speaking Anxiety (PRPSA) survey. While twenty-three (23) students volunteered for the qualitative focus-group interview, regarding the in-depth discussions on the implications of TPS and the different type of audiences with respect to their PSA.

\subsection{Materials}

To measure the PSA of the student participants, the study uses the McCroskey (1970) PRPSA survey; a validated scale strictly tailored for public speaking anxiety. PRPSA is a 34 item, 5-Likert (1932) scaled survey with an alpha reliability of higher than 0.90. Participants are asked to rate from five (5) scales (Strongly Disagree $=1$, Disagree $=2$, Neutral $=3$, Agree $=4$, or Strongly Agree $=5$ ); on various statements regarding speech anxiety. Scoring is accomplished by computing the following: $72-$ (Sum of the scores for items 4, 6, 7, 8, 11, 12, $15,16,17,18,24$, and 26) + (Sum of the scores for items 1, 2, 3, 5, 9, 10, 13, 14, 19, 20, 21, 22, 23, 25, 27, 28, $29,30,31,32,33$, and 34). Furthermore, the total score should fall between 34 and 170, and if the score is below 34 or above 170, there must be a mistake in the computation. PSA is considered high if the score is above 131, low if below 98, and moderate if score is between 98 and 131 (McCroskey, 1970). (Please see appendix for a copy of the PRPSA)

Besides the PRPSA, the survey given to the student participants also includes some background information such as: age, gender, and other information. Most survey will combine nominal data on participants' backgrounds and relevant personal details with other scales (Weisberg, Kronsnick, \& Bowen, 1996). Surveys are often administered to a large number of respondents, hence, survey research are often coined to as quantitative research, which has a high level of structure and low level of researcher involvement with the study population (Axinn \& Pearce, 2006).

Lastly, the study also uses focus group interviews to further analyze the implications of TPS and the different type of audiences with respect to their PSA. Focus group interviews are among one of the most widely used qualitative research tools in social sciences studies (Axinn \& Pearce, 2006). A probable benefit of this approach is that interviewees may feel greater confidence in a group setting, which may encourage them to offer comments and discuss matters they would not in a one-on-one interview.

\subsection{Procedure}

The study took placed in the 2009-2010 school year; lasting from September 2009 till August 2010. Student participants are eighty-two (82) third-year students of a four-year technical-vocational college in Taiwan. All of the students were enrolled in a yearlong (two semesters) public speaking course. Since there are 82 participants, students are separated into two sections wherein classes are held by the same teacher. All the students are given the PRPSA as the pre/post survey to see whether the yearlong public speaking course is effective or not.

The yearlong public speaking course was structured wherein students undergoes speech training by providing various activities. During the first two months of the course, students are given lectures and activities geared towards the basic fundamental skills in public speaking, such as: posture, facial expressions, gestures, eye contact, and voice inflections (variations). This is then followed by a series of ten speaking assignments with 
various topics from the simplest form such as self introduction and the person I most admired (mostly narrative and descriptive speeches), to the more advanced such as the value of learning and the current problem in our society (mostly involving critical thinking and personal viewpoints).

For the simple speeches ( 5 speeches), students were graded by their teacher in terms of their speech performance (posture, facial expression, gestures, eye contact, etc.), structure or outline of the speech, and English grammar (including pronunciation and enunciation). PRPSA (pre-survey) was then administered to see the students' initial perception of PSA after the set of simple speeches. For the advanced speeches ( 5 speeches); this started during the $2^{\text {nd }}$ semester, besides their subject teacher, students are also graded by two other faculty from the department. In addition, each of the advanced speeches has other students from other classes as audience.

After the set of simple speeches, two focus group interview sessions was conducted on volunteer students. Questions regarding the effect of TPS with respect to their speeches are asked and comments collected and analyzed. Likewise, after the set of advanced speeches, two focus group interview sessions was also conducted on the same group of volunteer students from the previous interview sessions. Questions regarding the effects of gender and different audiences on their speeches were asked and comments collected and analyzed.

It is also noted that during the course program, before each individual speech presentations the teacher provides guides and lectures in how to go about with their speeches. Furthermore, during the advanced speeches, students are asked to group themselves into four to five members. Although the speeches are done individually, students work cooperatively and helped each other in finding ideas for their speeches. Lastly, as mentioned above, the PRPSA (post-survey) was administered again to the students to determine whether the yearlong public speaking course program is beneficial or not to the students PSA development.

\section{Data Analysis}

\subsection{Survey Reliability}

Reliability is a prerequisite for validity. Reliability is synonymous to dependability, consistency, and replicability over time, over instruments and over groups of respondents (Cohen, Manion, \& Morrison, 2007). In essence, for research to be reliable it must demonstrate that if it were to be carried out on a similar group of respondents in a similar context, then similar results would be found. In this study, after the items of the different factors are selected, Cronbach's Alphas (1951) was calculated using the Statistical Package for Social Sciences (SPSS) software. For the current study, the overall reliability was computed as $\mathbf{0 . 9 0}$. In general, reliability with values higher than 0.80 demonstrate very good reliability for research purposes (Hair, Anderson, Tatham, \& Black, 1998).

\subsection{Factor Analysis}

For the PRPSA survey results, besides computing for the total anxiety scores; factor analysis was also accomplish to determine the underlying concepts of the data gathered. Factor analysis is a method of grouping together variables (or items) which have something in common. It is a process which enables the researcher to take a set of variables and reduce them to a smaller number of underlying factors which account for as many variables as possible (Cohen et al., 2007). Factor analysis actually detects structures and commonalities in the relationships between variables. Therefore, factor analysis enables researchers to identify where different variables are in fact addressing the same underlying concepts.

\subsection{Paired-sample T-test}

In comparing the pre/post PRPSA survey scores for significant changes in PSA values, the T-test is utilized 
(Boneau, 1960). The paired-sample T-test is used when there is only one group of participants and data is collected in two separate times or under two different conditions. If the T-test result is significant, this means that the intervention used is effective (Cohen et al., 2007).

\subsection{Focus group interview}

With regards to the data gathered during the focus group interviews, the Miles and Huberman (1994) method for generating meaning from transcribed and interview data was used for data analysis. Their methods of noting patterns and themes; clustering items into categories; building logical chains of evidence through noting causality and making inferences; and making conceptual coherence allow typically large amounts of qualitative data to be reduced (Cohen et al., 2007). Furthermore, the data given by the interviewees such as TPS and the type of audiences were also tabulated and statistically analyzed using frequency and percentage.

\section{Results and Discussions}

This section presents and discusses the results of both the quantitative survey and qualitative focus-group data. In order to present the results more clearly, the following section shall be divided by means of the research questions.

\subsection{What are the underlying factors behind the students PSA?}

To determine the underlying factors behind the students PSA, factor analysis was accomplished on the results of the 34 item PRPSA (administered after the set of simple speeches). The data was first screened for uni-variate outliers. Out of range values were identified and were recorded as missing data. The minimum amount of data for factor analysis was satisfied, with a final sample size of 73 (using listwise deletion), with over 10 cases per variable (Bryman \& Cramer, 1990). During several steps, a total of ten items were eliminated because they did not contribute to a simple factor structure and failed to meet a minimum criteria of having a primary factor loading of 0.40 or above, and no cross-loading of 0.30 above.

The factorability of the remaining 24 items PRPSA was further examined with several well-established criteria in factor analysis. First, all of the 24 items correlated at least 0.30 with at least one other item, suggesting reasonable factorability. Second, the Kaiser-Meyer-Olkin (KMO) measure of sampling adequacy was computed to be $\mathbf{0 . 8 2 1}$, above the recommended value of 0.600 (Kaiser, 1970). While the Barlett's test of sphericity was significant with $\chi^{2}(276)=989.46$ and the associated probability is less than $0.05(p<0.000)$. Hence, the factor analysis is considered appropriate. Lastly, communalities were all above 0.50 , further confirming that each item shared some common variance with other items. (Please see table 1 for more details)

The principal component analysis with a varimax rotation to maintain orthogonality among the factors was conducted, with eight factors accounting for $70 \%$ of the total variance. All of the 24 items loaded cleanly on one of the six factors (a factor loading of 0.50 or greater on only one factor). Eight items loaded on the first factor which accounts for $20 \%$ of the explained variance and was labeled positive attitude towards speech anxiety (factor 1). Items loading on this factor pertained to the positive feeling a person has during the preparation and actual speech presentation. Six items loaded on the second factor which accounts for $16 \%$ of the explained variance and was labeled emotional consequences of speech anxiety (factor 2). Items loading on this factor pertained to the perceived emotional consequences a person feels during the preparation of the speech.

The third factor is labeled physical consequences of speech anxiety (factor 3) with two items which accounts for $11 \%$ of the explained variance. Items loading on this factor pertained to the perceived physical consequences a person feels during the preparation of the speech. The fourth factor is labeled insufficient preparation (factor 4 ) with two negatively worded items which accounts for $8 \%$ of the explained variance. Items loading on this factor pertained to the perceived consequences of insufficient speech preparation. While, the fifth factor is labeled felling of helplessness (factor 5) with two items which accounts for $8 \%$ of the explained 
Hsu, T. C.

variance. Items loading on this factor pertained to the perceived feeling of helplessness during the preparation of the speech. Lastly, the sixth factor is labeled perfectionist (factor 6) with two items which accounts for $7 \%$ of the explained variance. Items loading on this factor pertained to the perceived consequences of being perfectionist.

The naming of the factors is actually accomplished after the focus group interview, wherein the 23 volunteer participants were also asked regarding what they perceived the meaning of the items in the PRPSA. Furthermore, in order to make sense of these underlying factors towards the students' PSA; correlation analysis was also accomplished. The Pearson Product Moment Correlation Coefficient to be exact or more common known as Pearson's correlation or Pearson's $\boldsymbol{r}$, is the most widely used measure of correlation or association (Cohen et al., 2007). The product moment part of the name comes from the way in which it is calculated, by summing up the products of the deviations of the scores from the mean. Correlation is a measure of the strength of relationship between at least two continuous variables. The value for a Pearson's can fall between $\mathbf{0 . 0 0}$ (no correlation) and 1.00 (perfect correlation). Other factors such as group size will determine if the correlation is significant. Generally, by using the software SPSS, correlations above $\mathbf{0 . 8 0}$ are considered as pretty high.

Table 1

Factor analysis of the PRPSA $(n=73)$

\begin{tabular}{|c|c|c|c|}
\hline Items & Loading & Communality & Mean $^{\mathrm{a}}$ \\
\hline Factor 1: Positive attitudes towards speech anxiety & & & 2.19 \\
\hline I face the prospect of giving a speech with confidence & 0.825 & 0.724 & 2.11 \\
\hline I do not dread giving a speech & 0.774 & 0.792 & 2.16 \\
\hline $\begin{array}{l}\text { I feel that I am in complete possession of myself while giving a } \\
\text { speech }\end{array}$ & 0.767 & 0.718 & 2.36 \\
\hline I look forward to giving a speech & 0.750 & 0.685 & 2.12 \\
\hline I feel relaxed while giving a speech & 0.739 & 0.648 & 2.16 \\
\hline I enjoy preparing for a speech & 0.733 & 0.708 & 2.07 \\
\hline I have no fear of giving a speech & 0.707 & 0.673 & 2.19 \\
\hline My mind is clear when giving a speech & 0.632 & 0.736 & 2.40 \\
\hline Factor 2: Emotional consequences of speech anxiety & & & 1.95 \\
\hline While giving a speech I get so nervous I forget facts I really know & 0.825 & 0.797 & 2.00 \\
\hline I feel anxious while waiting to give my speech & 0.740 & 0.765 & 1.88 \\
\hline I do poorer on speeches because I am anxious & 0.683 & 0.582 & 2.03 \\
\hline I am in constant fear of forgetting what I prepared to say & 0.668 & 0.638 & 1.93 \\
\hline $\begin{array}{l}\text { I get anxious if someone asks me something about my topic that I } \\
\text { do not know }\end{array}$ & 0.615 & 0.485 & 1.89 \\
\hline I get anxious when I think about a speech coming up & 0.531 & 0.595 & 1.96 \\
\hline Factor 3: Physical consequences of speech anxiety & & & 2.15 \\
\hline I breathe faster just before starting a speech & 0.843 & 0.755 & 2.25 \\
\hline $\begin{array}{l}\text { Certain parts of my body feel very tense and rigid while giving a } \\
\text { speech }\end{array}$ & 0.685 & 0.672 & 2.25 \\
\hline My heart beats very fast just as I start a speech & 0.622 & 0.721 & 1.92 \\
\hline $\begin{array}{l}\text { I experience considerable anxiety while sitting in the room just } \\
\text { before my speech starts }\end{array}$ & 0.600 & 0.677 & 2.21 \\
\hline
\end{tabular}


Table 1 ... continued

Factor analysis of the PRPSA $(n=73)$

\begin{tabular}{|c|c|c|c|}
\hline Items & Loading & Communality & Mean $^{\mathrm{a}}$ \\
\hline Factor 4: Insufficient preparation & & & 2.08 \\
\hline $\begin{array}{l}\text { My thoughts become confused and jumbled when I am giving a } \\
\text { speech }\end{array}$ & 0.719 & 0.714 & 2.00 \\
\hline My hands tremble when I am giving a speech & 0.640 & 0.657 & 2.15 \\
\hline Factor 5: Feeling of helplessness & & & 2.57 \\
\hline I have trouble falling asleep the night before a speech & 0.839 & 0.827 & 2.73 \\
\hline $\begin{array}{l}\text { During an important speech I experience a feeling of helplessness } \\
\text { building up inside me }\end{array}$ & 0.547 & 0.686 & 2.41 \\
\hline Factor 6: Perfectionist & & & 2.20 \\
\hline $\begin{array}{l}\text { When the instructor announces a speaking assignment in class I } \\
\text { can feel myself getting tense }\end{array}$ & 0.822 & 0.813 & 2.29 \\
\hline $\begin{array}{l}\text { When I make a mistake while giving a speech, I find it hard to } \\
\text { concentrate on the parts that follow }\end{array}$ & 0.718 & 0.794 & 2.12 \\
\hline
\end{tabular}

Note. ${ }^{\mathrm{a}}$ Mean scores of items.

Table 2, shows the result of the correlation analysis. Besides the six factors some other variables were also included in the computation, such as age, number of times the student joins a speech contest, number of times the student represent the school for competition, and the number of months in the Campus Toastmasters club. Campus Toastmasters Clubs are co-curricular activities with a sole purpose of helping their student members gain personal growth through the training of communication and leadership skills in a positive and cooperative environment (Toastmasters International District 67, 2009).

Within the 6 factors of the PRPSA, the factor Feeling of helplessness scored the highest with a mean of 2.57. Although this result shows a moderate sense of helplessness, further analysis shows that around $10 \%$ (around 1 in every seven students felt this way). This means that students felt left alone and nobody seems willing to help them. Such comments were also raised during the focus group sessions.

I am very afraid when it comes to my turn doing the speeches. I know I did not prepare well enough, but nobody will help me prepare. I am all alone. (FG-1, male student)

My classmates are all busy; everyone is doing their own speeches. I am a new here at this school,

I felt bad that nobody would help me. (FG-2, female student)

This is followed by the factors Perfectionist and Positive attitudes towards speech anxiety with means of 2.20 and 2.19 respectively. Since the PRPSA (pre-survey) is given at the middle of the course (after the set of simple speeches), the results hinted that students are still not that keen towards the importance of English speech proficiencies. More importantly, the students still felt uncomfortable and unsure of their own potentials. Some students mentioned that they are still not capable of handling themselves during speeches.

Talking in front of other people is scary. Even though I am one of the top students in class, I still felt uncomfortable. (FG-1)

For the rest of the PRPSA factors physical consequences of speech anxiety, insufficient preparation, and emotional consequences of speech anxiety, with means of 2.15, 2.08, and 1.95 respectively. Such results are actually positive, since the data shows that students PSA is not that serious.

With regards to the results of the correlational analysis, data suggest that those students who represent the school for speech competitions also felt strongly towards the factor Positive attitudes towards speech anxiety 
Hsu, T. C.

(factor 1) with r (73) $=0.455, p<0.01$. Furthermore, students who joined the campus Toastmasters $\boldsymbol{c l u b}$ are also the one who represent the school for speech competitions with $\mathrm{r}(73)=0.518, p<0.01$. This goes to show that the cooperative processes involved in the campus Toastmasters club is beneficial to the students. With regards to the effect of age and PSA, data suggest that the older the student the less they felt the sense of helplessness with $\mathrm{r}(73)=0.301, p<0.05$. This is quite expected as with more mature students are, the more they are capable of handling themselves and seek help from others.

Table 2

Correlation analysis of the factors $(N=73)$

\begin{tabular}{|c|c|c|c|c|c|c|c|c|c|c|}
\hline Items & & (1) & (2) & (3) & (4) & (5) & (6) & (7) & (8) & (9) \\
\hline Age & (1) & 1 & & & & & & & & \\
\hline Represent the school & (2) & -0.152 & 1 & & & & & & & \\
\hline Toastmasters member & (3) & 0.061 & 0.518 ** & 1 & & & & & & \\
\hline Factor 1 & (4) & -0.146 & $0.455^{* *}$ & $0.340 * *$ & $1(0.90)^{\mathrm{a}}$ & & & & & \\
\hline Factor 2 & (5) & -0.119 & 0.115 & 0.003 & $0.355^{* *}$ & $1(0.85)^{\mathrm{a}}$ & & & & \\
\hline Factor 3 & (6) & -0.137 & 0.008 & 0.089 & $0.294 *$ & 0.650 ** & $1(0.83)^{\mathrm{a}}$ & & & \\
\hline Factor 4 & (7) & -0.037 & 0.133 & 0.098 & $0.273 *$ & $0.622 * *$ & $0.582^{* * *}$ & $1(0.60)^{\mathrm{a}}$ & & \\
\hline Factor 5 & (8) & $-0.301 *$ & 0.031 & 0.041 & 0.206 & $0.515^{* *}$ & $0.393^{* *}$ & $0.312 * *$ & $1(0.68)^{\mathrm{a}}$ & \\
\hline Factor 6 & (9) & -0.133 & -0.057 & 0.074 & $0.265^{*}$ & $0.514 * *$ & $0.472^{* *}$ & $0.409 * *$ & $0.531 * *$ & $1(0.72)^{\mathrm{a}}$ \\
\hline
\end{tabular}

Note. ${ }^{\mathrm{a}}$ Alpha coefficient. $* p<0.05$ and ${ }^{* *} p<0.01$.

With the rest of the factors, results show that they are quite correlated with each other. Such result could only indicate that the factors are quite related to each other (Cohen et al., 2007). This would mean that the students are quite consistent with their opinion in the PRPSA. In essence, results of the factor analysis and correlation analysis of the PRPSA (pre-survey) shows the underlying factors both shows how and why the students exhibits PSA. With the current better understanding of the underlying factors, changes in the public speaking course program can be made to help diminish the students' PSA.

\subsection{To what extent can gender differences affects PSA and TPS?}

To answer this question, results of the focus group interviews are tabulated and analyzed. Table 3 shows the data regarding gender difference and TPS. Results also revealed that around $30.4 \%$ students spent four to six hours to prepare for a speech. Most of interviewees indicate that if they spend longer time in preparation, their anxiety will decrease.

For each of the speech that I made, I will spend around 4 to 6 hours of preparation. I will start by writing a draft of my speech, and then I will try to memorize it and watch myself in the mirror as I recite the speech. (FG-3, female student)

Furthermore, results also show that female students have more TPS than their male counterparts. However, such result doesn't mean that male students would feel less or more PSA than their female counterparts. In essence, results show that male students lack proper speech practices before delivering their speeches.

For me, speeches are easy. I'm not saying that I don't feel afraid when I'm up on stage. But I just don't want to prepare as hard as the other students does. (FG-4, male student)

For the gender difference in PSA, table 4 shows that around 60\% (21.74\% male, 39.13\% female) of the 
A study on the EFL students' speech related anxiety in Taiwan

interviewed participants mentioned that they experienced anxiety before the speech. In addition, around $30 \%$ $(8.70 \%$ male, $21.74 \%$ female) of the interviewed participants mentioned that they experienced anxiety during the speech. While only $10 \%$ ( $8.7 \%$ female) participants mentioned that they experienced anxiety both before and during their speech. The results also show that female students experienced more PSA than their male student counterpart. Although female students have more TPS, it still seems that they experienced more PSA. Further analysis have shown that female students are more prone to being grade consciousness and afraid of feeling bad in front of their classmates than male students.

Table 3

Gender difference in TPS $(n=23)$

\begin{tabular}{|c|c|c|c|c|}
\hline TPS (hours) & Male & $(\%)$ & Female & $(\%)$ \\
\hline $0-1$ & 2 & $(8.70)$ & 0 & (0) \\
\hline $2-3$ & 2 & $(8.70)$ & 3 & (13.04) \\
\hline $4-6$ & 1 & $(4.35)$ & 6 & (26.09) \\
\hline $7-9$ & 1 & $(4.35)$ & 3 & (13.04) \\
\hline $10-12$ & 1 & $(4.35)$ & 0 & (0) \\
\hline $13-15$ & 0 & $(0)$ & 4 & (17.39) \\
\hline Total & 7 & $(30.43)$ & 16 & (69.57) \\
\hline
\end{tabular}

I always practice and practice on my own. I don't want to act badly in front of my classmates. (FG-4, female student)

For me, completing the speech is fine. I don't care much of my grade. (FG-3, male student)

It seems different when even you practiced a lot of times at home. My grades are still not that high, I am still afraid of doing my speeches. I am afraid to make mistakes. (FG-3, female student)

\section{Table 4}

Gender difference in PSA $(n=23)$

\begin{tabular}{|c|c|c|c|}
\hline PSA & Male (\%) & Female $(\%)$ & $\%$ \\
\hline Before speech & $5 \quad(21.74)$ & $9 \quad(39.13)$ & 60 \\
\hline During speech & $2 \quad(8.70)$ & $5 \quad(21.74)$ & 30 \\
\hline Both & $\begin{array}{ll}0 & (0)\end{array}$ & $2 \quad(8.70)$ & 10 \\
\hline Total & $7 \quad(30.43)$ & $16 \quad(69.57)$ & 100 \\
\hline
\end{tabular}

\subsection{To what extent can gender differences and the different type of audiences affect the reported levels of PSA?}

To answer this question, results of the focus group interviews are tabulated and analyzed. Table 5 shows the data regarding gender difference and different type of audiences. Results have shown that female students experienced less PSA with familiar audiences, but on the contrary felt high PSA with unknown audiences. Furthermore, female students seem to exhibit higher PSA than male students as long the students are not familiar with the audiences. 


\section{Table 5}

Gender difference and PSA in different type of audiences $(n=23)$

\begin{tabular}{ccc}
\hline Items & Male $(\%)$ & Female $(\%)$ \\
\hline
\end{tabular}

Familiar audience

More anxious

About the same

Less anxious
2 (8.70)

$0 \quad(0)$

1 (4.35)
2 (8.70)

$0 \quad(0)$

3 (13.04)

Unknown audience

More anxious

About the same

Less anxious
2 (8.70)

$0 \quad(0)$

1 (4.35)
4 (17.39)

$0 \quad(0)$

1 (4.35)

More audience

More anxious

2 (8.70)

About the same

$0 \quad(0)$

$0 \quad(0)$

Less anxious

$0 \quad(0)$

$0 \quad(0)$

Gender difference audience

More anxious

$\begin{array}{ll}0 & (0)\end{array}$

2 (8.70)

About the same

$0 \quad(0)$

$0 \quad(0)$

Less anxious

$0 \quad(0)$

$\begin{array}{ll}0 & (0)\end{array}$

\section{Authoritative audience}

More anxious

$0 \quad(0)$

$2 \quad(8.70)$

About the same

$0 \quad(0)$

$0 \quad(0)$

Less anxious

$\begin{array}{ll}0 & (0)\end{array}$

\subsection{What are the advantages/disadvantages brought about by the yearlong public speaking course?}

To determine the effectiveness of the course program, pre/post PRPSA survey scores was collected and analyzed. A paired sample t-test was conducted to evaluate the impact of the yearlong public speaking course program on the students PRPSA scores. Results show that there was a significant decrease in PRPSA scores from Pre-survey $($ Mean $=123.74$, Standard Deviation $=17.64)$ to Post-survey $($ Mean $=91.23$, Standard Deviation $=$ 8.72), $\mathrm{t}(73)=17.11, p<0.001$. The eta squared statistics $(\mathbf{0 . 8 0})$ indicated a very large effect (Cohen et al., 2007). The results also show that there was an average decreased of 32.51 PRPSA scores per students; from a moderately high PSA to a moderately low PSA. These results all pointed to the benefits of the yearlong program towards PSA in general. However, to determine a more detailed result of the benefits, qualitative focus group interview data was analyzed by means of Miles and Huberman (1994) generation of meaning from repeating issues.

Table 6 shows the skills affected by the yearlong public speaking program. In general, students mentioned that they improved most on their writing skills (39\%) and body language or gestures (39\%). This was followed by eye contact with $34 \%$ and fluency with $26 \%$. In essence, students claimed that the yearlong public speaking course program do indeed helped them improve their overall English speech proficiency and diminished their 
PSA significantly.

Table 6

Skills affected by the yearlong public speaking course $(n=23)$

\begin{tabular}{|c|c|c|c|}
\hline Items & Male (\%) & Fema & $e(\%)$ \\
\hline Writing skills & $4 \quad(17)$ & 5 & $(22)$ \\
\hline Voice inflections & $0 \quad(0)$ & 1 & (4) \\
\hline Eye contact & $1 \quad(4)$ & 7 & (30) \\
\hline Body language & $1 \quad(4)$ & 8 & $(35)$ \\
\hline Fluency & 2 (9) & 4 & (17) \\
\hline Self-confidence & $3 \quad(13)$ & 1 & (4) \\
\hline Interaction & $0 \quad(0)$ & 1 & (4) \\
\hline Visual aids & $2 \quad(9)$ & 2 & (9) \\
\hline Pause & $0 \quad(0)$ & 1 & (4) \\
\hline Gain experience & $1 \quad(4)$ & 0 & $(0)$ \\
\hline Transition phrases & $1 \quad(4)$ & 0 & $(0)$ \\
\hline No improvement & $1 \quad(4)$ & 0 & $(0)$ \\
\hline
\end{tabular}

\section{Conclusions}

To summarize, findings suggests that there are a lot of different factors that could cause anxiety, such as different type of audiences, being grade conscious, and many others. In reality, even though female students have more TPS, they experience more PSA than their male student counterparts, and this is primarily because they (female students) are more conscious with their grades. However, in a general sense, PSA is quite normal, it happens to most of us. In the good side, the yearlong public speaking course program has positively contributed to the overall students' English speech proficiency. Moreover, the reported level of PRPSA dropped significantly at the end of the course program. As this study is only limited to the students of a technical-vocational college, findings are restricted to this context. However, with the recent influx of such type of universities in Taiwan, more studies are urged to further develop new effective teaching methodology. In addition, factors such as students' personality, self-perceptions, beliefs, attitudes, intelligence, teaching style, classroom and campus climate, and many others should be included in the assessment of the various causes and implications of PSA.

\section{References:}

Aida, Y. (1994). Examination of Horwitz, Horwitz, and Cope' construct of foreign language anxiety: The case of students of Japanese. The Modern Language Journal, 78, 155-168. $<$ http://dx.doi.org/10.1111/j.1540-4781.1994.tb02026.x >

Axinn, W. G., Fricke, T. E., \& Thornton, A. (1991). The microdemographic community-study approach: Improving survey data by integrating the ethnographic method. Sociological Methods and Research, 20(2), 187-217. <http://dx.doi.org/10.1177/0049124191020002001>

Axinn, W. G., \& Pearce, L. D. (2006). Mixed method data collection strategies. New York: Cambridge University Press. <http://dx.doi.org/10.1017/CBO9780511617898>

Bassano, S., \& Christison, M. (1987). Developing successful conversation groups. In M. Long \& J. Richards (Eds.), Methodology in TESOL: A book of readings (pp. 201-207). Boston: Heinle \& Heinle.

Beatty, M. J. (1988). Situational and predisposition correlates of public speaking anxiety. Communication Education, 37(1), 28-39. <http://dx.doi.org/10.1080/03634528809378701>

Beatty, M. J., Behnke, R. R., \& McCallum, K. (1978). Situational determinants of communication apprehension. Communication Monographs, 45, 187-191. <http://dx.doi.org/10.1080/03637757809375964> 
Hsu, T. C.

Behnke, R. R., \& Sawyer, C. R. (2001). Patterns of psychological state anxiety in public speaking as a function of anxiety sensitivity. Communication Quarterly, 49, 85-94. $<$ http://dx.doi.org/10.1080/01463370109385616>

Boneau, C. A. (1960). The effects of violations of assumptions underlying the t test. Psychological Bulletin, 57(1), 49-64. <http://dx.doi.org/10.1037/h0041412>

Bryman, A., \& Cramer, D. (1990). Quantitative data analysis for social scientists. London: Routledge.

Bygate, M. (1987). Speaking. Oxford: Oxford University Press.

Campbell, C. M., \& Shaw, V. M. (1994). Language anxiety and gender differences in adult second language learners: Exploring the relationship. In C. A. Klee (Ed.), Faces in a crowd: The individual learner in multi-section courses (pp. 47-80). Boston: Heinle \& Heinle.

Chen, C. F. (2001). The relationship between English learning experience, English anxiety and English comprehension ability of the junior high school students. Unpublished Masteral thesis, National Kaohsiung Normal University, Kaohsiung, Taiwan.

Cheng, Y.-S., Horwitz, E. K., \& Schallert, D. L. (1999). Language anxiety: Differentiating writing and speaking components. Language Learning, 49(3), 417-446. <http://dx.doi.org/10.1111/0023-8333.00095>

Chorpita, B. F., \& Barlow, D. H. (1998). The development of anxiety: The role of control in the early environment. Psychological Bulletin, 124, 3-21. <http://dx.doi.org/10.1037/0033-2909.124.1.3>

Chuo, Z.-T. (2005). A study of foreign language learning anxiety, in-class activities, and instructors' behaviors in STUT. Unpublished Masteral thesis, Tainan University of Technology, Tainan, Thesis.

Clément, R., Dörnyei, Z., \& Noels, K. A. (1994). Motivation, self-confidence, and group cohesion in the foreign language classroom. Language Learning, 44(3). $<$ http://dx.doi.org/10.1111/j.1467-1770.1994.tb01113.x>

Clements, K., \& Turpin, G. (1996). Physiological effects of public speaking assessed using a measure of palmar sweating. Journal of Psychophysiology, 10, 283-290.

Cohen, L., Manion, L., \& Morrison, K. (2007). Research methods in education. New York: Routledge.

Cronbach, L. J. (1951). Coefficient alpha and the internal structure of tests. Psychometrika, 16, 197-334. $<$ http://dx.doi.org/10.1007/BF02310555>

Ellis, R. (1994). The study of second language acquisition. Oxford: Oxford University Press.

Ghaith, G. M. (2002). The relationship between cooperative learning, perception of social support, and academic achievement. System, 30(3), 263-273. <http://dx.doi.org/10.1016/S0346-251X(02)00014-3>

Hair, J. F., Jr., Anderson, R. E., Tatham, R. L., \& Black, W. C. (1998). Multivariate data analysis. Englewood Cliffs, NJ: Prentice-Hall.

Haywood, C., \& Mac an Ghaill, M. (2003). Men and masculinities: Theory, research and social practice. Buckingham: Open University Press.

Horwitz, E. K., Horwitz, M. B., \& Cope, J. A. (1991). Foreign language classroom anxiety. In E. K. Horwitz \& D. J. Young (Eds.), Language anxiety: From theory and research to classroom implications (pp. 27-36). Englewood Cliffs: New Jersey: Prentice Hall.

Horwitz, E. K., \& Young, D. J. (Eds.). (1991). Language anxiety: From theory and research to classroom implications. Englewood, NJ: Prentice Hall.

Hsu, S. (2008). Foreign language anxiety among technical college students in English class. Unpublished Masteral thesis. Nanya Institute of Technology, Taoyuan, Taiwan.

Johnson, B., \& Christensen, L. (2008). Educational research - Quantitative, qualitative, and mixed approaches (3rd ed.). Thousand Oaks, CA: Sage Publications.

Kaiser, H. (1970). A second generation Little-Jiffy. Psychometrika, 35, 401-415. $<$ http://dx.doi.org/10.1007/BF02291817>

Kenneth, E., \& Melvin, R. (2008). Foreign language anxiety in Japanese EFL university classes: Cause, coping, and locus of control. Electronic Journal of Foreign Language Teaching, 5(2), 181-191.

Likert, R. (1932). A technique for the measurement of attitudes. New York: Columbia University Press.

MacIntyre, P. D., \& Gardner, R. C. (1989). Anxiety and second-language learning: Toward a theoretical clarification. Language Learning, 39, 251-275. $<$ http://dx.doi.org/10.1111/j.1467-1770.1989.tb00423.x>

McCroskey, J. C. (1970). Measures of communication-bound anxiety. Speech Monographs, 37, 269-277. $<$ http://dx.doi.org/10.1080/03637757009375677>

McCroskey, J. C. (1984). The communication apprehension perspective. In J. A. Daly \& J. C. McCroskey (Eds.), Avoiding communication: Shyness, reticence, and communication apprehension (pp. 13-38). Beverly Hills, CA: Sage.

McCroskey, J. C., \& Beatty, M. J. (1984). Communication apprehension and accumulated communication state anxiety experiences: A research note. Communication Monographs, 51, 79-84. 
A study on the EFL students' speech related anxiety in Taiwan $<$ http://dx.doi.org/10.1080/03637758409390185>

McCroskey, J. C., Daly, J. A., \& Sorensen, G. A. (1976). Personality correlates of communication apprehension: A research note. Human Communication Research, 2, 376-380. $<$ http://dx.doi.org/10.1111/j.1468-2958.1976.tb00498.x>

Merriam, S. B. (1998). Qualitative research and case study applications in education. San Francisco: Jossey Bass.

Miles, M., \& Huberman, M. (1994). Qualitative data analysis (2nd ed.). Beverly Hills, CA: Sage.

Ministry of Education. (2010). 2010 educational statistics [In Chinese]. Retrieved August 5, 2011, from http://www.edu.tw/statistics/content.aspx?site_content_sn=9088

Misra, R., \& McKean, M. (2000). College students' academic stress and its relation to their anxiety, time management, and leisure satisfaction. American Journal of Health Studies, 16(1), 41-55.

Myers, D. G. (1999). Social psychology (6th ed.). Holland, MI: McGraw-Hill Company.

Nunan, D. (2003). The impact of English as a global language on educational policies and practices in the Asia-Pacific region. TESOL Quarterly, 37(4), 589-613. <http://dx.doi.org/10.2307/3588214>

Paalhar, S. L. (2001). Gender difference in public speaking anxiety. Retrieved January 5, 2001, from http://clearinghouse.missouriwestern.edu/manuscripts/226.php

Payne, U., \& Carlin, D. (1994). Getting started in public speaking. Chicago, IL: National Textbook Company.

Richards, J., \& Renandya, W. (2002). Methodology in language teaching: An anthology of current practice. Cambridge: Cambridge University Press. <http://dx.doi.org/10.1017/CBO9780511667190>

Slavin, R. E. (1980). Cooperative learning. Review of Educational Research, 50(2), 315-342. $<$ http://dx.doi.org/10.3102/00346543050002315>

Spielberger, C. (1983). Manual for the state-trait anxiety inventory (STAI-Form Y). Palo Alto, CA: Consulting Psychologists Press.

$\mathrm{Su}$, M. (2005). A study of technological and vocational college students' language strategies and their self-perceived English proficiency. Electronic Journal of Foreign Language Teaching, 2(1), 44-56.

Sun, Y. C. (2008). The Toastmasters approach: An innovative way to teach public speaking to EFL learners in Taiwan. RELC Journal, 39(1), 113-130. <http://dx.doi.org/10.1177/0033688208091143>

Toastmasters International District 67. (2009). Dig more, reap more. Retrieved December 27, 2009, from http://www.toastmasters.org.tw/

Verderber, R., \& Verderber, K. (2003). The challenge of effective speaking. Belmont, CA: Wadsworth/Thomson.

Weisberg, H. F., Kronsnick, J. A., \& Bowen, B. D. (1996). An introduction to survey research, polling, and data analysis (3rd ed.). Thousand Oaks, CA: Sage.

$\mathrm{Wu}$, J. Y. (2004). The correlation between language anxiety and English speaking proficiency for the 3rd-graders and the 6th-graders in an elementary school. Unpublished Masteral thesis, National Cheng Kung University, Tainan, Taiwan.

Yin, R. K. (1984). Case study research: Design and methods. Newbury Park, CA: Sage.

Young, D. J. (1990). An investigation of students' perspectives on anxiety and speaking. Foreign Language Annals, 23(6), 539-553. <http://dx.doi.org/10.1111/j.1944-9720.1990.tb00424.x> 
Hsu, T. C.

Appendix

Personal Report of Public Speaking Anxiety (PRPSA) survey by McCroskey (1970)

1. While preparing for giving a speech, I feel tense and nervous.

2. I feel tense when I see the words "speech" and "public speech" on a course outline when studying.

3. My thoughts become confused and jumbled when I am giving a speech.

4. Right after giving a speech I feel that I have had a pleasant experience.

5. I get anxious when I think about a speech coming up.

6. I have no fear of giving a speech.

7. Although I am nervous just before starting a speech, I soon settle down after starting and feel calm and comfortable.

8. I look forward to giving a speech.

9. When the instructor announces a speaking assignment in class, I can feel myself getting tense.

10. My hands tremble when I am giving a speech.

11. I feel relaxed while giving a speech.

12. I enjoy preparing for a speech.

13. I am in constant fear of forgetting what I prepared to say.

14. I get anxious if someone asks me something about my topic that I don't know.

15. I face the prospect of giving a speech with confidence.

16. I feel that I am in complete possession of myself while giving a speech.

17. My mind is clear when giving a speech.

18. I do not dread giving a speech.

19. I perspire just before starting a speech.

20. My heart beats very fast just as I start a speech.

21. I experience considerable anxiety while sitting in the room just before my speech starts.

22. Certain parts of my body feel very tense and rigid while giving a speech.

23. Realizing that only a little time remains in a speech makes me very tense and anxious.

24. While giving a speech, I know I can control my feelings of tension and stress.

25. I breathe faster just before starting a speech.

26. I feel comfortable and relaxed in the hour or so just before giving a speech.

27. I do poorer on speeches because I am anxious.

28. I feel anxious when the teacher announces the date of a speaking assignment.

29. When I make a mistake while giving a speech, I find it hard to concentrate on the parts that follow.

30. During an important speech I experience a feeling of helplessness building up inside me.

31. I have trouble falling asleep the night before a speech.

32. My heart beats very fast while I present a speech.

33. I feel anxious while waiting to give my speech.

34. While giving a speech, I get so nervous I forget facts I really know. 